\title{
Kriminalizácia homosexuality v Československu \\ (1918-1938) - nástupníckom štáte \\ Rakúsko-Uhorska. Zmeny, vplyvy, paralely
}

The Criminalization of Homosexuality in the Czechoslovak Republic (1918-1938) - the successor state of the Austro-Hungarian Empire. Changes, Impacts, Parallels

Michal Mako / mizuumako@gmail.com

Historický ústav, Filozofická fakulta, Masarykova univerzita, Brno, CZ

\begin{abstract}
The Article deals with the criminalization of homosexuality after the disintegration of AustroHungarian Empire, an important European power unit, in its successor state - the Czechoslovak Republic. It describes the transformation of the legislation of criminalization of homosexuality after the dissolution of the constitutional dualistic monarchy and the creation of a new democratic republic on its territory. It captures the impacts of the newly-formed state on the position of homosexual minority society and its legal forms of persecution. It monitors the European parallels and differences in the disintegration of the state entities and the subsequent access to criminalization of homosexuality in their new state entities and units in the same historical period.
\end{abstract}

\section{Keywords}

Austro-Hungarian Empire; criminalization; criminal law; homosexuality; the Czechoslovak republic; queer history 


\section{1 Úvod}

51 ročný historický príbeh Rakúsko-Uhorska ukončila prvá svetová vojna. Rozpad vel'kej európskej mocnosti priniesol začiatok nových národných, kultúrnych, hospodárskych či sociálnych príbehov. Odraz značných politických a štátoprávnych zmien je možné vybadat vo viacerých oblastiach spoločenského života. V nasledujúcej kapitole sa budem zaoberat́ vplyvom rozpadu štátneho mocenského celku Rakúsko-Uhorska na zmeny právneho postihu homosexuality v Československu. Priniesol koniec monarchistického štátneho celku koniec kriminalizácie homosexuality na jeho novorozdelenom území?

Cielom príspevku je načrtnút vybrané aspekty, ktoré podnecovali právnu perzekúciu homosexuality v Československu. Elementárnym ciel’om je analýza dopadov zániku rakúsko-uhorskej štátnej moci na právny prístup k homosexualite v novoutvorenej štátnej jednotke. Okrem rozboru situácie v Československu pridám stručný popis vybraných európskych paralel a diferencií v tomto ohlade.

Príspevok je podložený spracovanými informáciami z primárnych archívnych a sekundárnych historických prameňov. Použité primárne archívne pramene sú najmä trestno-právneho, justičného a policajného charakteru. Vychádzajú z jurisdikcie Československa a výkonov jeho súdov. Hlavné spracované sekundárne historické pramene popisujú vývoj trestného práva na území niekdajšieho Československa. Ďalšie sa dotýkajú života homosexuálnej society a jej sexuálneho cítenia, ktoré bolo v dlhej perióde vývoja l’udskej spoločnosti zväčša sociálne neakceptovatelné. V práci využívam priamu, komparatívnu, induktívnu a deduktívnu metódu.

Chcel by som poukázat na rôznorodý charakter konca či rozpadu, ktorý predstavuje istú historickú realitu. Koniec môže podnecovat’ zrod podobného, celkom nového alebo nemusí figurovat ako kvalitatívna zmena. Široký rozmer konca alebo rozpadu je možné vysledovat vd’aka disparátnym uhlom pohladu bádatela v špecificky vybranej historickej problematike.

\section{Kriminalizácia homosexuality v Rakúsko-Uhorsku}

Modernizačný proces práva prebiehal v Európe v novovekom období, najmä na prelome 18. a 19. storočia. Pôvodne platné stredoveké obyčajové právo ${ }^{1}$ začalo nahrádzat právo moderné, vynucované štátom a jeho orgánmi. Vznikali nové ucelené celoštátne právne poriadky, ktoré tvorili súbor právnych noriem platiacich na celom území daného štátu. Tradičný teritoriálny a personálny právny partikularizmus determinovaný konkrétnym prostredím a časom zapríčinil, že na celoštátnej úrovni pôvodne neexistovalo jednotne kodifikované platné trestné právo. Ku kriminalizácii homosexuality sa tak pristupovalo rozličným spôsobom nielen v závislosti od konkrétneho regiónu štátu, ale aj v závislosti od časového obdobia.

1 Súbor tradičných, dlhodobo, záväzne platných pravidiel a noriem správania, ktorý vznikol na základe spoločenskej skúsenosti. Ottová, Eva: Teória práva. Šamorín 2010, s. 191-192. 
V habsburskej monarchii dochádza k prvotným snahám o zjednotenie trestnoprávneho poriadku, teda aj právneho postoja voči homosexualite, v 18. storočí. Prvý právny kódex, ktorý mal mat pôsobnost̉ na celom území českých krajín bol trestný zákonník Márie Terézie, tzv. Constitutio criminalis Theresiana z roku 1768. Homosexuálne akty² sa v zákonníku vydanom ústrednou štátnou autoritou postihovali hrdelnými trestami. ${ }^{3}$

O devätnást̉ rokov sa praktizovanie homosexuality vymanilo spod trestu smrti vd’aka cisárovi Jozefovi II. Osvietenský cisár prijal reformný V̌̌eobecný zákonnik o zločinoch a trestoch $\mathrm{v}$ roku 1787, ktorý v duchu osvietenstva odrážal zmenu pohladu na právny trest. Odteraz mal prispievat k prevýchove páchatel’a. Preto boli zrušené všetky hrdelné tresty. ${ }^{4}$

Nový zákonník platný na území českých krajín kodifikoval v roku 1803 cisár František I. Po neúspešných revolúciách v rokoch 1848-1849 na uhorskom území vstúpil do platnosti vyššie spomenutý rakúsky trestný zákonník, čím sa skončilo obdobie personálneho a teritoriálneho právneho partikularizmu aj v Uhorsku. V roku 1852 prebehla novelizácia Františkovho zákonníka, ${ }^{5}$ ktorej cielom bolo dokonalejšie zjednotenie trestného práva všetkých krajín habsburskej monarchie. ${ }^{6}$

Po roku 1860 nastala v Uhorsku malá zmena. Po páde Bachovho absolutizmu a vydaní Októbrového diplomu sa vrátil stav spred roku 1848. Zároveň sa na stretnutí judexkuriálnej konferencie v Budapešti pracovalo na vytvorení nového uhorského práva. ${ }^{7}$

Stručný popis vývoja moderného práva v habsburskej monarchii je dôležitý pre pochopenie právneho stavu aplikovaného na území staronového európskeho mocenského útvaru, novoutvorenej konštitučnej dualistickej monarchie Rakúsko-Uhorska. Jej zrod ukotvil zákonný článok č. XII./1867, podpísaný 28. júla 1867, všeobecne známy ako rakúsko-uhorské vyrovnanie. Dve hlavné časti monarchie, rozdelené hraničnou riečkou Litava na Predlitavsko a Zalitavsko, boli spojené osobou panovníka a tromi spoločnými ministerstvami. Rozdelené boli v otázke občianstva, súdnictva, volebného a právneho systému. Ku kriminalizácii homosexuality tak pristupovali rozličným spôsobom.

V Uhorsku, respektíve Zalitavsku, bol ako prvý uhorský trestný zákonník s celoplošnou pôsobnostou kodifikovaný zákonným čl. 5/1878 tzv. Uhorský trestný zákonnik o zločinoch a prečinoch ${ }^{8}$ (d’alej uh. tr.z.). V rakúskej časti monarchie, respektíve Predlitavsku,

2 Pre súdobé označenie homosexuálnych aktov sa používal biblický pojem „sodomia“ alebo aj slovné spojenie „smilstvo proti prírode/prirodzenosti“.

3 Seidl, Jan: Úsilí o odtrestněni homosexuality za proni republiky. Nepublikovaná rigorozní práce. Historický ústav FF MU. Brno 2007, s. 17.

4 Himl, Pavel: Proti prirozenosti. Stejnopohlavní vztahy v předmoderních dějinách českých zemí. In: Miluji tvory svého pohlaví. Homosexualita v dějinách a společnosti českých zemí. Edd. P. Himl - J. Seidl F. Schindler. Praha 2013, s. 38.

5 Prijatie zákona č. 117/1852 r.z.

6 Mosný, Peter a kol.: Dejiny štátu a práva na územi Slovenska. Banská Bystrica 2010, s. 133.

7 Judexkuriálna konferencia zasadala v dňoch 23.1.-4.3.1861. Schôdza vypracovala zbierku s názvom „Dočasné súdne pravidlá“, ktorá položila základy moderného právneho poriadku Uhorska. Stipta, István: Dejiny súdnej moci v Uhorsku do roku 1918. Košice 2004, s. 49.

8 Autorom zákonu bol Károly Csemegi (*3. 5. 1826, † 18. 3. 1899), mad’arský profesor trestného práva na Univerzite v Budapešti. Beňa, Jozef - Gábriš, Tomáš: Dejiny práva na územi Slovenska I. (do roku 1918). Bratislava 2008, s. 190. 
platil nad’alej zákon č. 117/1852 r.z., ktorým sa prijal Rakúsky trestný zákonník o zločinoch, prečinoch a priestupkoch (d’alej rak. tr.z.). Oba právne dokumenty platili na území Rakúsko-Uhorska až do jeho rozpadu v roku 1918.

Na uhorskom území sa $\mathrm{k}$ homosexualite pristupovalo po právnej stránke nasledovne. O homosexuálnych stykoch pojednávala Hlava XIV. uh. tr.z., „Zločiny a prečiny proti cudnosti“. Dobrovol'né vykonanie homosexuálneho aktu bolo definované v $\$ 241$ uh. tr.z.: „Smilstvo medzi mužmi a smilstvo človeka so zvieratom je prečinom smilstva proti prírode a potresce sa väzenim do roka“. ${ }^{9}$ Násilné smilstvo proti prírode postihoval $\$ 242$ uh. tr.z.: „Smilstvo proti prírode je zločinom a potresce sa žalárom do pät’ rokov, ak bolo spáchané medzi mužmi násilím alebo hrozbou; ked' však spôsobil zločin smrt’ poškodeného, potresce sa doživotnou trestnicou“. ${ }^{10}$ Rovnako-pohlavné smilstvo medzi ženami trestné nebolo. ${ }^{11}$

V rakúskej časti monarchie postihovala homosexuálne správanie Hlava XIV. rak. tr.z., „O násilném smilstuu, zprzněni a jiných těžkých př́padech smilstva“. Homosexualita je definovaná v $\$ 129$ rak. tr.z.: „I. Proti př́rodě. Jako zločiny trestaji se též dalši způsoby smilstva : I. smilstvo proti přirodě, to jest: $a$, se zviŕaty; $b$, s osobami téhož pohlavi. "12 Trest bol v porovnaní s uhorským zákonníkom tažší. Vymeriaval sa v 130 rak. tr.z.: „Trestem toho jest těžký žalár od jednoho až do pěti let. "13 Ak bolo spáchané násilné, nedobrovolné smilstvo (§ 125 rak. tr.z.), trest bol vymeraný na 5 až 10 rokov žalára. Ak došlo pri sexuálnom čine k ublíženiu na zdraví či živote, páchatelovi hrozilo 10 až 20 rokov žalára. Napokon ak bola sexuálnym stykom spáchaná smrt’ poškodeného, udelený bol trest tažkého doživotného žalára (§ 126 rak. tr.z.).

Ani jeden z paragrafov trestajúcich homosexualitu na území Rakúsko-Uhorska neupresňoval, ktoré sexuálne praktiky je potrebné považovat’ za smilstvo proti prírode. $\mathrm{V}$ praxi to znamenalo, že rôzne súdy konajúce v trestnom konaní voči homosexuálnej činnosti mohli posudzovat rôznym spôsobom naplnenie skutkovej podstaty trestného činu. ${ }^{14}$ Vo všetkých odvolaniach voči rozhodnutiam súdov nakoniec figurovala judikatúra kasačného súdu, teda viedenského najvyššieho súdneho dvora. Ten definitívne rozhodoval vo veci naplnenia skutkového stavu trestného činu. ${ }^{15}$

Trestnoprávny status homosexuality dopíňam stručným priblížením miery perzekúcie, aby som uviedol aspoň rámcovú predstavu o priamom vplyve trestných paragrafov na život homosexuálnych občanov žijúcich na území českých krajín. ${ }^{16} \mathrm{Z}$ dostupnej trest-

9 Zák. čl. 5/1878. Uhorský trestný zákonník o zločinoch a prečinoch. \$ 241.

10 Tamže, $\$ 242$.

11 Výnimkou boli prípady podla $\S 243$ a $§ 244$ uh. tr.z., iba ak išlo o zločin krvismilstva.

12 Zák. č. 117/1852 r.z. Rakúsky trestný zákonník o zločinoch, prečinoch a priestupkoch. § 129.

13 Zák. č. 117/1852 r.z. Rakúsky trestný zákonník o zločinoch, prečinoch a priestupkoch. § 130.

14 Jeden z príkladov poskytuje trestný prípad Antona D., ktorý bol prvotne obžalovaný a súdený na Okresnom súde v Michalovciach, po odvolaní na Krajskom a Vrchnom súde v Košiciach. Viac v práci: Mako, Michal: Kriminalizácia homosexuality v 1. ČSR na priklade Košického regiónu. Nepublikovaná diplomová práca. Katedra histórie FF UPJŠ v Košiciach. Košice 2017, s. 71-76.

15 Seidl, Jan a kol.: Od žaláře k oltárí. Emancipace homosexuality v českých zemích od roku 1867 do současnosti. Brno 2012, s. 25.

16 Detailnejšiu predstavu o policajnom stíhaní konkrétnych prípadov homosexuality a právnych postupoch, 
nej štatistiky územia českých krajín vyplýva, že v rokoch 1914 až 1918 bolo pre zločin $\S$ 129 až $§ 131$ rak. tr.z. odsúdených spolu 283 osôb starších ako 14 rokov. ${ }^{17}$ Išlo o hlavné trestné činy, vedlajšie sa v dobovej trestnej štatistike neuvádzajú.

Presnejšie informácie zachytávajúce trestný postih homosexuality v českej časti územia Rakúsko-Uhorska prináša až výskum historika Jana Seidla a jeho spolupracovníka Lukáša Nozaru. Tí zrealizovali náročný archívny výskum s náhl’adom k judikatúre troch krajských (zemských) súdov v rozmedzí rokov 1898 až 1949 - v Prahe, Plzni a Hradci Králové. Výsledky tak zachytávajú čiastočný stav miery kriminalizácie homosexuality v druhej polovici existencie Rakúsko-Uhorska. Pre ilustráciu početnosti stíhania homosexuálnych aktivít prikladám tabul'ku č. 1 .

Tabul'ka č. 1: Minimálny počet doložených obvinení, obžalovaní a odsúdení mužov za § 129 b, rak. tr.z. na území českých krajín v období Rakúsko-Uhorska

\begin{tabular}{|l|l|l|l|}
\hline & obvinení & obžalovaní & odsúdení \\
\hline Praha $^{18}$ & 96 & 47 & 29 \\
\hline Plzeňn $^{19}$ & 7 & 7 & 2 \\
\hline Hradec Králové & & 11 & 6 \\
\hline spolu & 14 & 65 & 37 \\
\hline
\end{tabular}

* v sledovanom obdobi je doložené minimálne jedno obvinenie ženy ${ }^{21}$

Miera perzekúcie homosexuality v období Rakúsko-Uhorska postupne narastala. Počas vojnových rokov 1914-1918 poklesla vo všetkých troch sledovaných súdnych obvodoch. ${ }^{22}$ Po prvej svetovej vojne opät začala stúpat. Nárast počtu osôb perzekvovaných pre homosexuálne styky po vojne zrejme ako výrazný faktor podnietil vznik hnutia za ich dekriminalizáciu. ${ }^{23}$

o výkone štátnej moci vzhl’adom k perzekúcii homosexuality ponúka napr. práca: Seidl, J. a kol: Od žaláře k oltáríi, s. 19-32.

17 Trestní statistika z Čech, Moravy a Slezska v letech 1919-1922. Praha 1925, s. 12.

18 Údaje reflektujú výkon obvodu zemského (krajského) súdu trestného v Prahe v rokoch 1898, 1903, 1908, 1913, 1918 súhrnne. Seidl, Jan: Od žalář k oltárí, s. 39.

19 Údaje reflektujú výkon obvodu krajského súdu v Plzni v rokoch 1898, 1903, 1908, 1913, 1915,1917 súhrnne. Tamže, s. 42.

20 Údaje reflektujú výkon obvodu krajského súdu v Hradci Králové v rokoch 1898, 1903, 1908, 1913, 1915, 1917 súhrnne. Tamže, s. 44.

21 Jediná obvinená žena za $\$ 129$ b, rak. tr.z. v Prahe zo skúmaných rokov 1898, 1903, 1908 a 1913 súhrne. V Plzni bol realizovaný archívny výskum stíhania žien za $\$ 129$ b, rak tr.z. až po roku 1939. V Hradci Králové sa archívny výskum nezaoberal trestným stíhaním žien za § 129 b, rak. tr.z. Tamže, s. 39-44.

22 Hypoteticky z dôvodu verbovania mužov do vojny, kedy došlo k obmedzeniu príležitostí pre páchanie trestného smilstva proti prírode. Takisto v tažkých vojnových rokoch zrejme nebolo dostatok snahy stíhat občanov v danej trestnej veci. 


\section{Zmeny. Rozpad Rakúsko-Uhorska a kriminalizácia homosexuality v novovzniknutej stredoeurópskej republike}

Dualistická konštitučná monarchia, významná európska mocnost’, končí svoju existenciu po prvej svetovej vojne. O jej rozpade rozhodovali vítazné mocnosti vojny na Parížskej mierovej konferencii od 18. 1. 1919. V sérii prijatých medzinárodných zmlúv doslova rozložili Rakúsko-Uhorsko na niekol'ko nových nezávislých štátnych útvarov. Vzniklo tak samostatné a nezávislé Československo, Rakúsko, Mad’arsko, Královstvo Srbov, Chorvátov a Slovincov. ${ }^{24}$ Obnovilo sa Pol’sko, zväčšilo sa územie Rumunského a Talianskeho královstva.

Rozpad Rakúsko-Uhorska prijímali rôzne časti jeho obyvatel’stva odlišným spôsobom. Pre niektorých bol rozpad konečnou bodkou za obdobím národnostného útlaku a slastným zadostučinením dovtedajšieho boja za národné ciele. Česi a Slováci mali konečne vlastný štát s vlastnou mocou, ktorý si mohli spravovat demokratickým spôsobom samostatne. Nie však vo všetkých sférach spoločnosti nastala radost'. Vel'ká štátoprávna zmena neznamenala v trestnoprávnej oblasti pre homosexuálnu societu žiaden prelom.

Novovzniknutá demokratická Československá republika prevzala právny poriadok rozpadnutého Rakúsko-Uhorska tzv. kardinálnym ustanovením, článkom II. zákona č. 11/1918 Zb. z. a n., čo znamenalo, že všetky dovtedajšie zemské a ríšske zákony a nariadenia ostali načas v platnosti. Recipovanie starého rakúsko-uhorského práva malo byt dočasným riešením, kým sa nevytvorí na základe prevzatého súboru platných noriem nové unifikované československé právo. To malo odstránit rozdielny charakter uhorského a rakúskeho trestného zákonníka. ${ }^{25} \mathrm{Z}$ dočasného riešenia sa však stalo riešenie trvalé. Počas celého obdobia existencie Československa (1918-1938) platil na území tohto unitárneho štátu stav tzv. právneho dualizmu. ${ }^{26}$ Úsilie kodifikovat a unifikovat československé právo reprezentovalo viacero snáh a pokusov. Ani jeden z nich však nemal počas tohto obdobia úspech. ${ }^{27}$ Navyše, aj keby ho mal, zmenu v trestnosti homosexuality by nepriniesol.

Predložené návrhy nových trestných zákonov nad’alej obsahovali tresty za homosexuálne styky, a to napriek rastúcej snahe aktivistov v boji o dekriminalizáciu homosexuality v Československu. ${ }^{28}$ Ako príklad môže poslúžit jeden z posledných vládnych návrhov trestného zákona z roku 1937 - Osnova zákona, kterým se vydává trestni zákon (d’alej len osn. z.). Ponúka nám obraz prístupu vládnej moci a trestného práva k homosexualite v posledných rokoch existencie predmníchovského Československa. Homosexuálne smilstvo sa v novom návrhu vyskytuje nad’alej. Zmena nastala v použití termínu, ktorý ho definoval. Označenie smilstva

24 Skrátene Královstvo SHS. Od roku 1929 tzv. Juhoslovanské královstvo.

25 Uhorský trestný zákonník bol mladší, mal modernejší ráz a humánnejšie nazeranie na páchatel’a. Vojáček, Ladislav - Kolárik, Jozef - Gábriš, Tomáš: Československé právne dejiny (1918-1992). Bratislava 2011, s. 179. Potvrdzuje to napríklad aj prístup k homosexuálnym trestným činom.

26 V prvých rokoch existencie Československa dokonca stav tzv. právneho trializmu, ked’že československá oblast' Hlučínska používala nemecký právny poriadok. Na území Hlučínska sa rozšírila platnost̉ rakúskeho práva neskôr. Mosný, Peter a kol.: Dejiny štátu a práva na územi Slovenska. Banská Bystrica 2010, s. 240.

27 Beňa, Jozef: Vývoj slovenského právneho poriadku. Banská Bystrica 2001, s. 18-28.

28 Kvalitné spracovanie snáh o dekriminalizáciu homosexuality v Československu ponúka práca: Seidl, Jan: Úsili o odtrestněni homosexuality za proni republiky. Nepublikovaná rigorózní práce. Historický ústav FF MU. Brno 2007. 
proti prírode vystriedal termín „Smilstvo s osobou téhož pohlaví“. Nachádzal sa v $\$ 335$ osn. z.: „(1) Kdo vykoná smilné jednáni s osobou téhož pohlaví, bude potrestán tuhým vězením od jednoho měsice do jednoho roku. (2) Kdo však přiměje osobu téhož pohlavi mladší než osmnáct let, aby s ním vykonala smilné jednáni nebo aby na sobě trpěla jeho smilné jednáni, nebo kdo ji k tomu svádi, bude potrestán žalářem do tři let, neni-li jeho čin trestný př́sněji podle paragrafu $325 .{ }^{29}$ (3) Kdo provozuje po živnostensku smilstvo s osobou téhož pohlavi nebo kdo se po živnostensku nabizi k smilstvu s osobou téhož pohlavi, bude potrestán žalářm od jednoho roku do pěti let. "30

Vládna novela trestného zákona z roku 1937 sa zdá byt’ v porovnaní so súdobými platnými československými trestnými zákonmi v prístupe k homosexualite o čosi miernejšia. V dobrovolnom styku osôb rovnakého pohlavia sa priklonila k trestom § 241 uh. tr.z. V násilnom homosexuálnom styku sa znížila trestná sadzba na tri roky, ale iba v prípade, ak nedošlo k takému styku s osobami mladšími než 14 rokov. Zmena ešte nastala v pridaní state o postihovaní smilstva proti prírode zo zištných príčin, prostitúciou.

Mieru právnej perzekúcie v období prvej republiky reflektujú bohatšie zastúpené historické zdroje, ktoré prinášajú konkrétnejšie a širšie informácie. K výskumu judikatúry krajských súdov v Prahe, Plzni a Hradci Králové pribudli aj Brno a Košice.

Tabul'ka č. 2: Minimálny počet doložených obvinení, obžalovaní a odsúdení mužov za homosexuálne činy v Československu (1918-1938)

\begin{tabular}{|c|c|c|c|}
\hline & obvinení & obžalovaní & odsúdení \\
\hline Praha $^{31}$ & 190 & 199 & 131 \\
\hline Plzeň32 & 78 & 41 & 24 \\
\hline Hradec Králové ${ }^{33}$ & 39 & 25 & 14 \\
\hline medzisúčet & 307 & 265 & 169 \\
\hline Brno $^{34}$ & 242 & 194 & 147 \\
\hline Košice 35 & 37 & 21 & 14 \\
\hline spolu celkom & 586 & 480 & 330 \\
\hline
\end{tabular}

* $\quad v$ sledovanom obdobi je doložených súhrne 33 obvineni, obžalovani a odsúdeni žien za \$ 129 b, rak. tr.z. v českých krajinách $^{36}$

29 „Kdo vykoná smilné jednání s osobou mladší než čtrnáct let, bude potrestán žalářem od jednoho roku do pěti let; vykoná-li však s ženou mladší než čtrnáct let soulož, bude potrestán žalářem ode dvou do desíti let. "Osnova zákona, kterým se vydává trestní zákon. § 325. 1937.

30 Osnova zákona, kterým se vydává trestní zákon. 1937.

31 Údaje reflektujú výkon Krajského súdu v Prahe v trestnej veci $§ 129$ b, rak. tr.z. v rokoch 1918, 1923, 1928, 1933 a 1938 súhrnne (údaj o obvinených za rok 1938 chýba). Seidl, J. a kol: Od žaláře k oltárí, s. 39.

32 Údaje reflektujú výkon Krajského súdu v Plzni v trestnej veci § 129 b, rak. tr.z. v rokoch 1919, 1924, 1929, 1931, 1932, 1934 a 1939 súhrnne. Tamže, s. 42.

33 Údaje reflektujú výkon Krajského súdu v Hradci Králové v trestnej veci § 129 b, rak. tr.z. v rokoch 1919, 1924, 1929 a 1934 súhrnne. Tamže, s. 44.

34 Údaje reflektujú výkon Krajského súdu v Brne v trestnej veci § 129 b, rak. tr.z. v rokoch 1930-1939. Valtus, Ondřej: Perzekuce homosexuality v obvodu Krajského soudu trestního v Brně ve 30. letech 20. století. Nepublikovaná diplomová práce. Ústav pomocných věd historických a archivnictví FF MU. Brno 2015, s. 20-29.

35 Údaje reflektujú výkon Krajského súdu v Košiciach v trestnej veci § 241 (spolu obvinených, obžalovaných a odsúdených 35 osôb) a § 242 (spolu obvinených, obžalovaných, odsúdených 37 osôb) uh. tr.z. v rokoch 1924-1938. Štátny archív v Košiciach, Krajský súd v Košiciach (1525) 1872-1949; Väznica Krajského súdu v Košiciach 1882-1937. Štátny okresný archív Košice-okolie, Okresný úrad v Košiciach 1923-1939. 
Pre relevantnost’ komparácie miery perzekúcie v období Rakúsko-Uhorska a Československa (1918-1938) môžeme využit iba údaje za krajské súdy v Prahe, Plzni a Hradci Králové, ktorých archívny výskum zasahuje do oboch historických období. Z tohto porovnania vyplýva nárast kriminalizácie homosexuality v judikatúre daných troch krajských súdov českých krajín. V porovnaní s predošlým historickým obdobím sa zvýšil právny postih prežívanej homosexuality v demokratickom Československu.

Uvedené výsledky archívneho výskumu perzekúcie homosexuality v Brne a Košiciach slúžia ako ilustrácia situácie v d’alších oblastiach Československa, v ktorých sa podobný archívny výskum vykonal. Na tomto mieste je nutné upozornit čitatela na fakt, že údaje za Krajský súd v Brne reflektujú až 10 rokov (1930-1939) súdneho výkonu. Výsledky archívneho výskumu v Košiciach odrážajú ešte dlhšie obdobie, respektíve súdny výkon až za 15 rokov. Z tohto dôvodu uvádzam v tabul'ke Košice a Brno separátne, ked’že výsledky za tieto mestá spôsobujú skreslenie porovnávania stavu perzekúcie homosexuality v období predmníchovského Československa s d’alšími jeho mestami.

\section{Vplyvy. Aspekty determinujúce kriminalizáciu homosexuality v Československu}

Právna perzekúcia homosexuality v Československu pokračovala v nadväznosti na predošlé obdobie a rakúsko-uhorskú právnu normu. Ku žiadnej významnej zmene v tejto oblasti nedošlo. Demokratizácia územia českých krajín, Slovenska a Podkarpatskej Rusi automaticky neznamenala zmenu statusu homosexuálnej society. Nad’alej ostali jej sexuálne aktivity právne postihované, zväčša politicky, kultúrne a spoločensky odmietané. A to aj napriek prihláseniu sa nového štátu k honosne znejúcim cielom ukotveným v samotnej Ústave Československej republiky: „My, národ Československý, chtějice upevniti dokonalou jednotu národa, zavésti spravedlivé řády v republice, zajistiti pokojný rozvoj domoviny československé, prospěti obecnému blahu všech občanů tohto státu a zabezpečiti požehnáni svobody přištím pokolenim [...], aby tato ústava $i$ všechny zákony naši země prováděny byly v duchu našich dějin stejně jako v duchu modernich zásad, obsažených v hesle sebeurčeni; nebot' chceme se pričleniti do společnosti národů jako člen vzdělaný, mírumilovný, demokratický a pokrokový. “37

Do istej miery je otázne, aký vecný obsah by malo napíňat slovné spojenie - národ vzdelaný, mierumilovný, demokratický a pokrokový. Interpretácia daných pojmov sa mohla v rozličných historických obdobiach menit', a to nielen v rovine časovej, ale aj v rovine miestnej. Celkovo majú tieto honosne znejúce pojmy skôr iba vágny charakter. Otázky trestnosti homosexuality nespadali pod predstavu realizácie významov týchto termínov v praxi. A to aj navzdory tomu, že podla Ústavy „[...] všichni obyvatelé republiky Československé požívaji v stejných mezích jako státni občané této republiky na jejím územi plné

36 Z toho 17 v Prahe. Seidl, J. a kol: Od žaláře k oltáři, s. 39. A 16 v Brne. Valtus, Ondřej: Perzekuce homosexuality, s. 23 .

37 Zák. č. 121/1920 Zb. Zákon ze dne 29. února 1920, kterým se uvozuje ústavní listina Československé republiky. 
a naprosté ochrany svého života i své svobody nehledic $k$ tomu, jakého jsou pưvodu, státní př́slušnosti, jazyka, rasy nebo náboženstvi“. 38

Homosexuálne styky sa tak ani v období demokratického Československa nevymanili spod trestných útrap a idey nebezpečnej anomálie nutnej potláčania. V otázke slobody sexuálneho správania nemali demokratizačné zmeny žiadnu priamu odozvu. Ide o pochopitel'ný stav, ked’že homosexualita bola z historickej perspektívy dlhodobo nihilizovaná a medzi širokou verejnostou posudzovaná ako nebezpečná či nežiaduca úchylka. Jej intoleranciu, nielen v československej spoločnosti, determinovala interakcia rôznorodých vplyvov a hladísk.

Vymedzujem minimálne tri klúčové, primárne aspekty. Zákonitým, tol’ko spomínaným a už predostretým východiskom intolerancie rovnakopohlavných stykov bol právno-legislatívny aspekt. Priamo zaručoval legitimitu stíhania homosexuálneho správania. Zaužívaný a platný trestnoprávny systém však odrážal mravné pohnútky, respektíve morálku spoločnosti, jej predstavy o správnosti bytia a prežívaní človeka.

Jedným zo základných faktorov budujúcich morálku spoločnosti je viera, najčastejšie reprezentovaná náboženstvom. To síce postupne vyprodukoval človek, no po svojom ukotvení v širších l’udských societach následne produkovalo aj mysel’ človeka. Výrazne ovplyvňovalo jeho pohlad na bytie či pozemský a posmrtný život. Vytváralo tak rámec správneho, prípadne nesprávneho l’udského konania a spôsobu života. Nábožensky motivovaná morálka spísaná v kanonickom práve často prenikala do tvorby sekulárnych zákonov, predovšetkým v rodinnej, manželskej či dedičskej časti práva. Jej prieniky si nemožno nevšimnút $\mathrm{v}$ prístupe $\mathrm{k}$ homosexualite. ${ }^{39}$

Krestanská vierouka a náuka ovplyvňovali myslenie Stredoeurópanov nepretržite od 9. storočia, kedy sa začalo výrazné pokrestančovanie tunajšieho obyvatel’stva. Š́renie kresţanstva v Európe malo za následok, že sa z Československa stala výrazne krestanská krajina, v ktorej hlavný vplyv získala jej katolícka vetva. ${ }^{40} \mathrm{Z}$ náboženského hladiska bolo vykonávanie homosexuality neprípustnou „ohavnostou“. ${ }^{41}$ Biblické zákony Levitika ju trestali smrtou. ${ }^{42}$ Plynula z nich preto silná neznášanlivosṫ homosexuálneho správania na našom území a tiež legitimizovala jeho trestnost’ v Rakúsko-Uhorsku, neskôr v Československu. ${ }^{43}$

Značný dosah na jej trestnost’ mal aj vedecký aspekt. O homosexualite ako o vedeckom, najmä sexuologickom, psychologickom a psychiatrickom probléme, sa diskutovalo naprieč celou Európou v období 19. a 20. storočia. I ked’ sa pohlady, názory a teórie

38 Tamže, § $106(2)$.

39 Dlhodobo sa v stredovekom sekulárnom a cirkevnom práve používal biblický pojem „sodomia“, pomenúvajúci homosexuálny styk. Odkazuje na hriechy obyvatelov biblického mesta Sodoma. Autorom pomenovania je arcibiskup a teológ 9. storočia, Hincmar z Remeša (* 806, † 882). Bližší popis: Mako, M.: Kriminalizácia homosexuality v 1. ČSR na príklade Košického regiónu, s. 31-38.

40 Dokazujú to napríklad sčítania l’udu v Československu z 15. 2. 1921 a 1. 2. 1930.

41 „Nesmieš nečisto obcovat’s mužom tak, ako sa pohlavne obcuje so ženou. To by bola ohavnost! “ Lv 18,22.

42 „Kto by obcoval s mužom tak, ako sa obcuje so ženou, obaja spáchali ohavnost', musia zomriet', ich krv bude na nich. “ Lv 20,13.

43 Širšie informácie: Mako, M.: Kriminalizácia homosexuality v 1. ČSR, s. 38-44. 
jednotlivých vedeckých osobností líšli, prevládal v tomto období všeobecný konsenzus, označujúci homosexualitu za nebezpečnú chorobu alebo nežiaducu anomáliu či degeneráciu. Javila sa preto ako škodlivá a nebezpečná pre spoločnost', hodná nápravy, trestu a zároveň liečby. ${ }^{44}$

Široký pohlad vedy mal výrazný vplyv na nepretržitú stigmatizáciu, medicinalizáciu a samotnú kriminalizáciu homosexuality vo väčšine krajín Európy, v Československu nevynímajúc. Nepomohli ani snahy niektorých, okrem iného aj slovenských a českých vedcov, lekárov či aktivistov, ktorí sa snažili o vyvrátenie jej konvenčných medicínskych prístupov. ${ }^{45} \mathrm{~V}$ tomto období neúspešne.

Okrem vplyvov, ktoré udržovali tradičný negatívny postoj k homosexualite, by som predsa len vyzdvihol jeden s pozitívnym účinkom. Vo vy̌šie popísaných aspektoch sa demokratizačný proces Československa v prístupe $\mathrm{k}$ homosexualite prejavil len v minimálnom rozsahu, prípadne vôbec. Napriek trestnému postihu a perzekúcii homosexuálnych „Živlov" sa v tomto období začína výraznejší proces emancipácie homosexuálnej society a zosilňuje sa boj o dekriminalizáciu jej sexuálnych túžob. A to aj vd’aka zaručenej slobode tlače, spolkového či zhromažd’ovacieho práva. ${ }^{46}$ Prostredníctvom nich sa umožnilo publikovanie angažovaných časopisov, zakladanie spolkov a organizácií, ktorých hlavným cielom bolo vyvolanie tlaku na dekriminalizáciu homosexuality v Československu. Nedá sa však povedat, že sa tieto aktivity nestretávali s odporom štátnej moci. ${ }^{47}$ Ide zrejme o jediný podstatnejší účinok rozpadu Rakúsko-Uhorska na demokratický štátny útvar Československa v tejto veci.

\section{Paralely. Vybrané podobnosti a diferencie kriminalizácie homosexuality $v$ širšom európskom kontexte}

Vo víre búrlivých politických zmien prvej polovice 20. storočia nevýrazne kulminoval prístup k homosexualite naprieč celým európskym kontinentom. V novovzniknutých nástupníckych krajinách Rakúsko-Uhorska, takisto ako v Československu, ostala homosexualita nad’alej kriminalizovaná. Situácia tak bola v novoutvorenom Rakúsku, Mad’arsku a Chorvátsku ${ }^{48}$ paralelná s Československom. Trestné právo v týchto krajinách prevzalo dovtedy platné zákonníky. Každý z nich postihoval homosexualitu právnym trestom. ${ }^{49}$

44 Viac: Sengoopta, Chandak: Otto Weininger: Sexualita a věda v císařské Vídni. Praha 2009, s. 132-153.

45 Seidl, Jan: Úsilí o odtrestněni homosexuality za proni republiky, s. 71-105.

46 Zák. č. 121/1920 Zb. Zákon ze dne 29. února 1920, kterým se uvozuje ústavní listina Československé republiky. § $113(1-3)$.

47 Prvé snahy o založenie spolku prišli už v roku 1923. V Prahe sa od roku 1931 vydával časopis „Hlas sexuální menšiny“. V Brne od roku 1932 časopis „Kamarád“. Mnohým aktivitám bránila štátna moc. Seidl, J. a kol: Od žalářre k oltárí, s. 147-187.

48 V celom Královstve SHS.

49 Rakúsko prevzalo pôvodný trestný zákonník z roku 1852. V Mad’arsku nad’alej platil uhorský trestný zákonník z roku 1878. V Chorvátsku, ktoré sa stalo súčastou Královstva SHS, bol stále platný rakúsky trestný zákonník z roku 1852. Situácia sa zmenila až 1. 1. 1930, kedy došlo k zjednoteniu trestného právneho poriadku v celom Juhoslovanskom královstve. Kondor-Langer, Mirjana: Zaštita prava LGBT osoba: zakono- 
Výnimkou boli tie rakúsko-uhorské územia, ktoré sa po jeho rozpade pripojili k už existujúcim štátnym útvarom. V oblasti Haliča, pripadnutom Pol’sku od roku 1918, sa homosexuálne styky netrestali, a to aj napriek tomu, že v obnovenej Pol’skej republike kontinuálne platili pôvodné trestné zákonníky bývalých okupantských krajín Rakúsko-Uhorska, Nemecka a Ruska. Trestné paragrafy smilstva proti prírode sa nevymáhali. Od roku 1932 vytvorilo Pol’sko vlastný trestný zákonník, v ktorom nebolo zahrnuté trestanie rovnako-pohlavných stykov. ${ }^{50}$

Južné Tirolsko a územie rakúskeho prímoria ${ }^{51}$ pripadli po rozpade Rakúsko-Uhorska Talianskemu královstvu. Na týchto územiach sa začal používat taliansky trestný zákonník z roku 1889, ktorý neobsahoval zákaz homosexuálnych stykov dospelých osôb v súkromí. Rovnako tu došlo ku dekriminalizácii homosexuality. ${ }^{52}$

Rumunské královstvo získalo bývalé uhorské Sedmohradsko. Rumunský trestný zákonník z roku 1878, po pripojení platný v Sedmohradsku, postihoval iba trestné činy homosexuálneho znásilnenia. Dobrovolné homosexuálne styky sa v trestnom zákonníku nevyskytovali. Sedmohradsko sa teda tiež vymanilo spod kriminalizácie rovnakopohlavných sexuálnych stykov, ale iba do roku 1937, kedy Rumunsko prijalo nový trestný zákonník krála Karola II., ktorý už prežívanie homosexuality trestal. ${ }^{53}$

Mimo Rakúsko-Uhorského kontextu sa v rovnakom období pozrime ešte na východ Európy. Zaujímavé postavenie, najmä v kontexte súčasného politického a kultúrneho prístupu Ruskej federácie k homosexualite, malo novovzniknuté sovietske Rusko. V aktuálnej situácii sa Ruská federácia aktívne snaží prostredníctvom práva zakázat tzv. „gay propagandu“. ${ }^{44}$ Viaceré krajiny EÚ, USA a takisto mnohí aktivisti za rovnoste, dodržiavanie ludských a občianskych práv či iné osobnosti označujú postup Ruska za diskriminačnú snahu s cielom legitimizovat’ neznášanlivost̉ homosexuálnej menšiny v ruskej spoločnosti. $^{55}$

darstvo i policija. Kriminalogija i socijalna integracija 23, 2015. Dostupné z: https://hrcak.srce.hr/index. php?show=clanak\&id_clanak_jezik=239666, citováno 16. 2. 2018.

50 Carroll, Aengus - Mendos, Lucas Ramón: State-Sponsored Homophobia: A world surwey of sexual orientation laws: criminalisation, protection and recognition. Geneva 2016. Dostupné z: http://ilga.org/downloads/2017/ILGA_State_Sponsored_Homophobia_2017_WEB.pdf, citováno 15. 2. 2018.

51 Rakúske prímorie tvoril polostrov Istria a mesto Terst so svojím zázemím.

52 Tamže, s. 33.

53 Homosexualitatea: o istorie de secole, plină de controverse. Transilvania Reporter. Mădălina Kadar (C2015, http://transilvaniareporter.ro/reportaj/homosexualitatea-o-istorie-de-secole-plina-de-controverse/, citováno 15. 2. 2018.

54 Informáciu priniesol napríklad britský denník. Russia passes anti-gay-law. The Guardian. Guardian News and Media Limited @2013-2018, https://www.theguardian.com/world/2013/jun/30/russia-passes-antigay-law, citováno 21. 2. 2018.

55 Bližšie informácie napríklad: Nobel laureates urge Putin to repeal gay propaganda law. Autonomous Nonprofit Organization „TV-Novosti“ (C2005-2018, https://www.rt.com/news/nobel-laureates-putin-gay-592/, citováno 21. 2. 2018; Ruský anti-gay zákon porušuje lidská práva, rozhodl soud v Štrasburku. Josef Mačí (C2017, https://www.seznamzpravy.cz/clanek/rusky-anti-gay-zakon-porusuje-lidska-prava-rozhodl-soud-ve-strasburku-33279, citováno 21. 2. 2018; Ako „dúhová“ je Európa? Rusi na chvoste, Slováci sú čoraz homofóbnejší. Newsandmedia.sk (C)1999-2016, https://aktualne.centrum.sk/ako-duhova-je-europa-rusi-na-chvoste-slovaci-su-homofobnejsi-nez-pred-rokom/zahranicie/europa/, citováno 21. 2. 2018; Vládny dokument Ministerstva zahraničných veci USA, Úradu pre demokraciu, ludské práva a prácu z roku 2013: United States Department 
Paradoxne, po oficiálnom zániku cárskeho Ruska v septembri 1917 sa na rozdiel od Československa Ruská republika dočkala právnej dekriminalizácie homosexuality. Ani po bol’ševickej Októbrovej revolúcii v novembri 1917 sa tento stav nezmenil. Všetky dovtedajšie trestné zákony boli po prevrate zrušené. Nové sovietske trestné zákonníky z rokov 1922 a 1926 obdobne nezmieňovali trestnost’ homosexuálnych prejavov. Formálna dekriminalizácia ale neznamenala, že homosexuálne správanie nemohlo byt predmetom trestného stíhania. V zákonníkoch síce absentovali zmienky o takomto konaní, no známe sú viaceré trestné procesy stíhania homosexuality v sovietskom Rusku v danom období. Popisujem tak špecifický príklad, ktorého odkazom je, že ani formálna, zdanlivo absolútne rozhodujúca zmena, nemusela za každých okolností modifikovat̉ realizovanie právneho postihu homosexuality. ${ }^{56}$

\section{Záver}

Prelomová politická a územnosprávna zmena v našom geografickom priestore priniesla rozličné dopady na jeho obyvatel'stvo. Čast̉ populácie sa tešila z konečného vítazstva v boji o vlastný národný demokratický štát. Koniec, rozpad dualistickej monarchie umožnil vytúžené reformy. Nezreformovalo sa však stanovisko práva demokratického československého štátu vzhladom k tým občanom, ktorí chceli beztrestne žit’ v súlade so svojou nekonvenčnou sexuálnou orientáciou. K žiadnej úprave antihomosexuálnych zákonov nedošlo. Kriminalizácia homosexuality sa počas obdobia prvej republiky nezmiernila, naopak zosilnela. Vzrástol počet stíhaných l’udí obvinených z páchania rovnakopohlavných sexuálnych stykov.

Udalost' rozpadu monarchie nemala nijaký významný vplyv na trestnoprávny prístup k homosexualite - ani negatívny, ani pozitívny. Nestala sa pre homosexuálnu populáciu Československa medzníkom. Zánik tak nebol skutočným koncom, ale ani začiatkom. Jediný pozitívny odraz udalostí v tomto období badat’ v tendenciách širšieho a silnejšieho boja aktivistov za dekriminalizáciu homosexuality prostredníctvom publikovania časopisov a zakladania spolkov, ktoré ale takisto narážali na štátny odpor.

V prvej časti článku som popísal stav a mieru trestnoprávnej kriminalizácie homosexuality v období Rakúsko-Uhorska. V druhej časti som sa zameral na prevzatie dovtedajšieho platného trestného práva v predmníchovskom Československu a poukázal na to, že demokratická zmena štátnosti nepriniesla pozitívny dopad na zločinnost̉ homosexuálnych stykov. Tretia čast’ príspevku pojednáva o vplyvoch determinujúcich trestné konanie voči homosexualite, ktoré ostali s predošlou historickou etapou totožné. Zároveň vyzdvi-

of State. Bureau of Democracy, Human Rights and Labor: Russia 2013 Human Rights report. 2013, https://www. state.gov/documents/organization/220536.pdf, citováno 21. 2. 2018.

56 Viac: Healey, Dan: Homosexual desire in Revolutionary Russia : the regulation of sexual and gender dissent. London 2001, s. 124-125. Pozri tiež článok významného ruského profesora Igora Kona uverejnený na: Russian national gay, lesbi, bisexual and transexual website: Moonlight love. Soviet Homophobia by Professor Igor Kon. Professor Igor Kon @ 1998, http://www.gay.ru/english/history/kon/soviet.htm, citováno 14. 2. 2018. 
huje jediný zaznamenaný pozitívny prínos demokratizačného procesu Československa v ohlade právneho postihu homosexuality.

$\mathrm{V}$ poslednej časti práce som upriamil pozornost̉ na rozličnú situáciu v jednotlivých územných častiach bývalého Rakúsko-Uhorska. Niektorým obyvatel’om sa vd’aka rozpadu mocnosti otvorila možnost’ prežívat svoju homosexuálnu orientáciu bez strachu z policajného stíhania. Potvrdzuje sa tým fakt, že koniec či rozpad má širokospektrálny charakter. Dôležitú úlohu tu zohrávajú rôzne faktory - či už geografické, časové, politické, kultúrne, hospodárske, sociálne alebo trestnoprávne. Možností je mnoho. Koniec v našom prípade znamenal právnu kontinuitu v oblasti kriminalizácie homosexuality.

\section{Resumé}

The disintegration of Austro-Hungarian Empire encouraged the start of new national, cultural, economic or social stories. The article dealt with the effects of fall of this European state power unit on changes in the legal persecution of homosexuality in its successor state - the Czechoslovak republic (1918-1938). The aim of the paper was to outline selected aspects that encouraged the legal punishment of homosexuality and to analyse the impact of the dissolution of Austro-Hungarian Empire on a legal approach to homosexuality. The article also provides a brief description of selected European parallels and differences in this topic. The results of the work show that no modification of anti-homosexual laws in Czechoslovakia occurred. The criminalization of homosexuality has not diminished. The event of the collapse of the monarchy had not significant impact on the criminal approach to homosexuality - neither negative nor positive. The fall was neither a real end, nor a start. The only positive reflection of the events in this period was the stronger and wider fight of activists for decriminalization of homosexuality through the publication of magazines and founding organizations, which also hinted at state and police resistance. In conclusion, the End may induce the formation of something similar, totally new or it does not have to be a qualitative change. The broad dimension of the End or the Decay can be tracked due to the disparate angle of the historian's view in a specifically chosen historical issue. 
